\title{
The Influence of Brand Image and Brand Love on Customer Loyalty Mediated by Customer Engagement: Study on Consumers of Wardah Cosmetics
}

\begin{abstract}
Rizqi Nurfitriana

Faculty of Economics and Business, University of Brawijaya, Malang, Indonesia, rizqi.nurfina@gmail.com

\section{Surachman}

Faculty of Economics and Business, University of Brawijaya, Malang, Indonesia,

Ananda Sabil Hussein Faculty of Economics and Business, University of Brawijaya, Malang, Indonesia,

Industrial cosmetics growth has increased every year. This situation makes a tight competition among the Cosmetic companies. Cosmetic companies try to create customer loyalty so they could sustain their business. Prior studies have examined variables that affect customer loyalty, yet only few studies have examined the effect of brand image, brand love and customer engagement in creating customer loyalty. This study aims to determine the effect of brand image, brand love, and customer engagement on customer loyalty of consumer Wardah Cosmetics in Malang. This study was explanatory with a quantitative approach and survey methode conducted on 150 respondents in Malang. Nonporbability sampling with purposive sampling technique was used. Data analysis process used by Partial Least Square (PLS). Results reveal that brand image and brand love has simultaneously significant effect on customer engagement. Brand love has significant effect on customer loyalty while brand image has no significant effect on customer loyalty. Customer engagement was also found to act as a mediator in this study. The results also reveal that customer engagement influences customer loyalty. The results of this study can prove helpful to practitioners about enhancing loyalty in their company based on brand image, brand love and customer engagement. The result of the research can also be a reference for future research.
\end{abstract}

Keywords: brand image; brand love; customer engagement customer loyalty

Received March 2019 | Accepted August 2020 | Available online August 2020

| DOI: http://dx.doi.org 10.18860/mec-j.v4i2.6251

\section{INTRODUCTION}

Indonesia as a developing country with the largest population is a potential market that has high growth. Seeing this considerable increase, Indonesia can become one of the potential markets for the cosmetics industry. The growth of the cosmetics industry in Indonesia is influenced by many factors, including the increasing demand for middlelevel consumers of high-quality cosmetic products, the trend in the use of cosmetics, which demands that many cosmetic producers meet market demand and the number of local and imported cosmetic brands in the Indonesian market. Seven hundred and sixty cosmetic companies are driving the growth of the cosmetics industry in Indonesia 
(Kemenperin, 2012) and one of the cosmetic industries that enliven the local market is Wardah cosmetics. Wardah cosmetics produces various skin care, hair care, and make-up products. At present Wardah has become one of the well-known cosmetic brands and best cosmetics companies in Indonesia with the achievement of various awards from year to year for several categories of cosmetics, such as TOP Brand Award at the Indonesia Customer Satisfication Award (ICSA) for the lipstick and powder category for the period 2013-2014.

Loyalty has been recognized widely as one of the important aspects in marketing research. Many previous studies have outlined the notion of loyalty (Engel et al., 1995; Lovelock and Wright, 2007; Kotler and Keller, 2012). According to Kotler and Keller (2012) there are several reasons why companies must maintain and maintain their customers, among others: costs incurred by the company in maintaining and retaining existing customers much smaller than looking for new customers, old consumers certainly have many positive experiences related to the company so they will try to defend the company, and refer the company to friends and the environment. Then, the importance of loyalty as a mechanism to survive in the market and become a competitive advantage for companies, makes many marketers trying to find ways to create it. Therefore, several studies still investigated the determinants of customer loyalty.

Some studies found that brand image is one of determinants of customer loyalty (Cho et al., 2015; Aaker, 1996; Kotler and Keller, 2012). According to Loureiro, Ruediger Kaufmann (2012) Islam and Rahman (2016) brand image will have a go od impact in creating loyalty because good image in a brand will directly give a positive perception to consumers of the product. Consumers will be easily affected by products that have a strong brand image on the product, because consumers do not need to look deeper into the product's in-depth information. A consumer will seek information on a product before making a purchase. Consumers who do not know the information about a product, then the consumer will prefer a well-known brand image or one he likes (Schiffman and Kanuk, 2008) .This is the reason that encourages companies to strengthen their brand position in order to create a brand image, consumers are able to recognize a product, evaluate quality, reduce the risk of purchase, and gain experience and satisfaction from the differentiation of certain products (Lin \& Lin, 2007) in other words a strong brand image in a product is expected to make consumers loyal to the brand.

Besides brand image, the variable that can affect customer loyalty is brand love. Brand love is a relatively new marketing concept that has not been widely studied by academics. Marketing research has examined various theories about consumer affective attitudes in valuing a brand. The assessment is the level of likes and dislikes of consumers assessing a brand. Brand love shows as a form of customer satisfaction with emotional response and passion based on their experience with a product brand. The love of the brand will be a strong foundation formed between consumers and brands that will allow consumers to voice their opinions and provide positive feedback to other consumers. After experiencing a high level of satisfaction that can affect consumers' 
love of the brand, consumers will be more loyal to the brand (Carrol and Ahuvia, 2006; Batra et al., 2012). Previous researches have proven that brand love has a positive relationship to brand loyalty. The consumer's love of the brand will cause consumers to repurchase a product that causes loyalty to the brand (Loureiro, Ruediger, Kaufmann, 2012).

Other variable acknowledging has an importance role in affecting customer loyalty is customer engagement. Previous marketing literature (Brodie et al. 2011; Hollebeek, 2011; So et al., 2014) stated that the consequence of customer engagement is loyalty. This happens because there is an assumption when customers are involved with the brand, they will carry out continuous interaction and build a strong emotional bond with the brand so that consumers will engage in loyalty behaviors such as repeat purchases, spread positive impressions, reluctance to change brands, etc. The relationship between customer and company engagement is important to achieve the company's competitive advantage as a way to establish loyalty without reason (Reitz, 2012). Customer engagement in this study will further be examined as a mediating variable on loyalty. Based on the description above, this study aim to determine the direct effect of brand image on customer loyalty; brand love on customer loyalty; brand image on customer engagement; brand love on customer engagement and determine the mediating effect of customer engagement on customer loyalty.

\section{THEORETICAL REVIEW}

\section{Customer Loyalty}

Current competition requires companies to develop strategies to attract good and right consumers. Consumer-based marketing is needed so that consumers become loyal. Hasan (2008) said that in the long run consumer loyalty is the goal of corporate strategic planning which is a company's competitive advantage. According to Kotler and Keller (2012) loyalty is defined as a strong held commitment to buy or subscribe to certain products or services in the future. Customer loyalty will be the key to success, not only in the short term but also in sustainable competitive advantage, despite the influence of the situation and marketing efforts that have the potential to cause behavior change. Griffin (2005) states that loyal customers have the following indicators: Make regular purchases or repeat purchases, recommend products or services to others, give positive comments about this brand.

\section{Customer Engagement}

Customer engagement is a concept that has not fully developed in marketing. The Marketing Science Institute (MSI, 2010) defines customer engagement as a manifestation of customer behavior towards brands (companies) outside of purchasing activities resulting from individual customer motivations such as word of mouth, recommendations, interaction between consumers, blogging, writing reviews and other similar activities. Customer engagement is creating a deep relationship with consumers that creates sustainable purchases, interactions and participation. The Economist Intelligence Unit states that customer engagement is a long-term, intimate relationship 
with customers. So et al. (2014b) defines customer engagement as a marketing activity oriented to customer behavior and psychology. This is reflected in the interaction of a customer with other customers or companies in a forum to obtain product information or anticipate the risks received if he consumes the product (Brodie et al., 2011).

Some marketing researchers have developed the concept of multidimensional customer engagement (Verhoef et al., 2010; Brodie et al., 2011; Hollebeek, 2011). Customer engagement is the customer's personal relationship to the brand as a manifestation of cognitive, affective and behavioral responses outside of purchasing activities (So et al., 2014b). There are five dimensions to measuring customer engagement, namely: enthusiasm, attention, absorption, interaction and identification (So et al., 2014b).

\section{Brand image}

Brand Image is a set of beliefs, ideas, and impressions that a person has towards a brand (Kotler and Armstrong, 2012). Brand image is a determinant of consumer attitudes in looking at a brand. In other words, the view of consumers towards a brand is determined by the brand image of the product. Another definition of brand image according to Kotler and Keller (2012) is the process by which someone chooses, organizes, and interpret information input to create a meaningful picture. According to Surjaatmadja (2008) states that brand image can sometimes change. When a brand image change is needed, a new role model must be found. As part of brand identification, the role model, should be able to represent the core identity elements of a brand. According to Salinas and Perrez (2009) brand image is measured by three indicators, namely: Functional image, Affective image and Reputation.

\section{Brand love}

Brand love is a level of emotional attachment that passionately satisfies consumers to have a brand (Carrol and Ahuvia, 2006). According to Batra et al. (2012) brand love is a combination of cognition, emotion, and attitude. Brand love stimulates consumer repurchase intention, positive word of mouth, resistance to negative information, and customer loyalty. According to Lewarissa (2012) a strong emotional bond from satisfied consumers will result in brand love. The creation of brand love will have an impact on the creation of customer loyalty for consumers to repurchase the product. According to Carroll and Ahuvia (2006) brand love measured by four namely, passion for the brand, positive evaluation of the brand, positive emotions in response to the brand, a statement of love for the brand.

\section{Hypothesis}

\section{The relationship between brand image on customer engagement Wardah Cosmetics}

Regarding brand image, previous research shows that brand image has a positive and significant influence on customer engagement (Bergkvist and Bech-Larsen, 2010; Carroll and Ahuvia, 2006; Doorn et al., 2010; Islam and Rahman, 2016).

H1: There is an influence between brand image on customer engagement Wardah Cosmetics

108 Management and Economics Journal (MEC-J)

Vol 4 (2) August 2020 
The relationship between brand love on customer engagement Wardah Cosmetics

Regarding brand love, previous research states that brand love is important in customer relationships with brands (Ismail and Spinelli, 2012).

H2:There is an influence between brand love on customer engagement Wardah Cosmetics

\section{The relationship between customer engagement on customer loyalty Wardah Cosmetics}

Some researchers state that customer engagement can increase loyalty and purchasing decisions (Hollebeek, 2011; Patterson et al., 2006).

H3: There is an influence between customer engagement on customer loyalty Wardah Cosmetics

\section{The relationship between brand image on customer loyalty Wardah Cosmetics}

Previous research states that the brand image or image of a brand will have a good impact on creating loyalty, because a good image in a brand will directly give a positive perception to consumers of the product (Loureiro, Ruediger, Kaufmann, 2012; Islam \& Rahman 2016).

$\mathbf{H 4}$ : There is an influence between brand image on customer loyalty Wardah Cosmetics

The relationship between brand love on customer loyalty Wardah Cosmetics

Brand love shows as a form of customer satisfaction with emotional response and passion based on their experience with a product brand. After consumers consume and experience a high level of satisfaction that can affect consumers' love of the brand, consumers will be more loyal to the brand (Carrol and Ahuvia, 2006).

H5: There is an influence between brand love on customer engagement Wardah Cosmetics

The relationship between brand image on customer loyalty through customer engagement Wardah Cosmetics

Previous research by (Vivek et al., 2012) states that customer engagement or customer engagement can lead to successful marketing results, such as loyalty, word-of-mouth, and cross-selling.

H6: There is an influence between between brand image on customer loyalty through customer engagement Wardah Cosmetics

The relationship between brand love on customer loyalty through customer engagement Wardah Cosmetics

Research also suggests that brand love is an important driver of engagement (Bergkvist and Bech-Larsen, 2010). When the customer is satisfied and a sense of love arises then he/she begins to have involvement with the brand that will trigger the customer will become loyal to the brand.

H7: There is an influence between brand love for customer loyalty through customer engagement products Wardah Cosmetics 


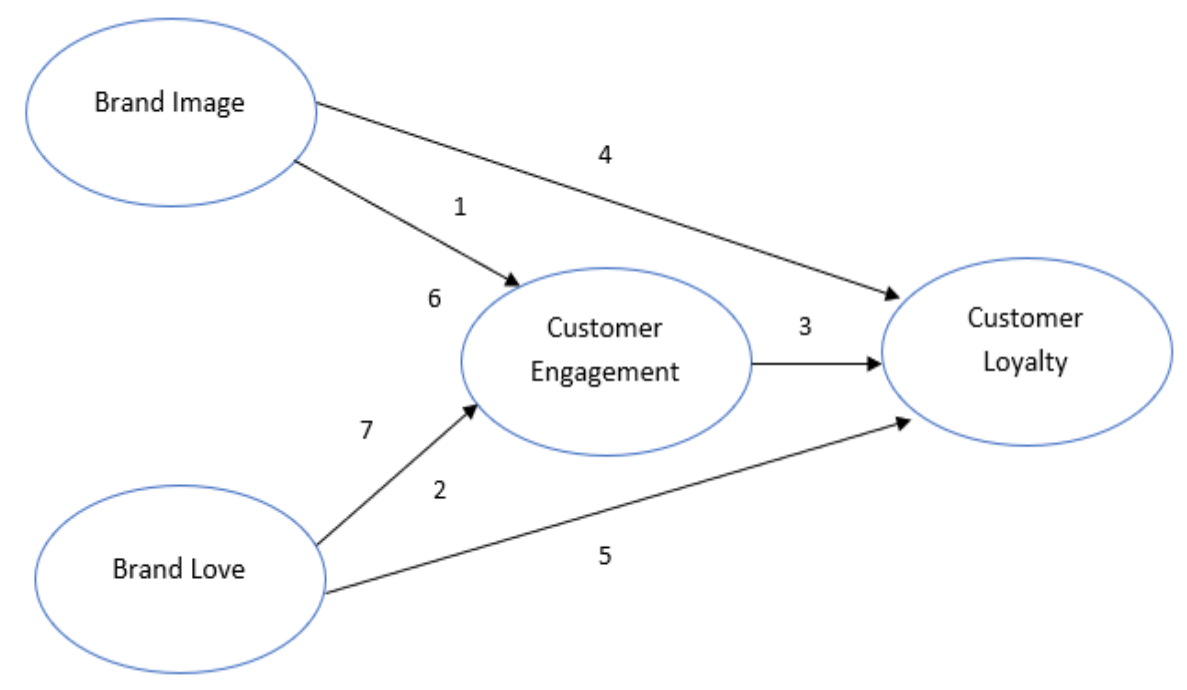

Figure 1. Research Model

\section{METHODOLOGY}

This research uses quantitative research approach. It is emphasizes on theories testing through measurement of research variables with numbers and data analysis using statistical procedure. Based on the research objectives, this is an explanatory research type (Sugiyono, 2011). This research is located in Malang City, with the population chosen being all users of Wardah products in Malang City. This study uses samples of 150 people. They are selected by nonprobabbility sampling method using purposive sampling technique. The research data can be divided into two sources namely primary data and secondary data. The research instrument is structured questionnaires. Questionnaires are a way of collecting data in form of questions sent or given directly to be filled and returned.

The validity instrument test was conducted on 150 respondents. The results then tested to determine the validity and reliability of the questionnaire as a research instrument. Validity and reliability tests in this study were using SPSS 25.0. Questionnaire items are said to be valid if the correlation value of each question item is above the cut off 0.3 . The research item is said to be reliable if the Cronbach Alpha coefficient value is $\geq 0.6$. PLS (Partial Least Square) is a variance-based structural equation analysis (SEM) that can simultaneously perform measurement models test and structural model test. The measurement model is used to test validity and reliability, while the structural model is used to test causality (hypothesis testing with prediction model). The model is shown in figure 2 below. 


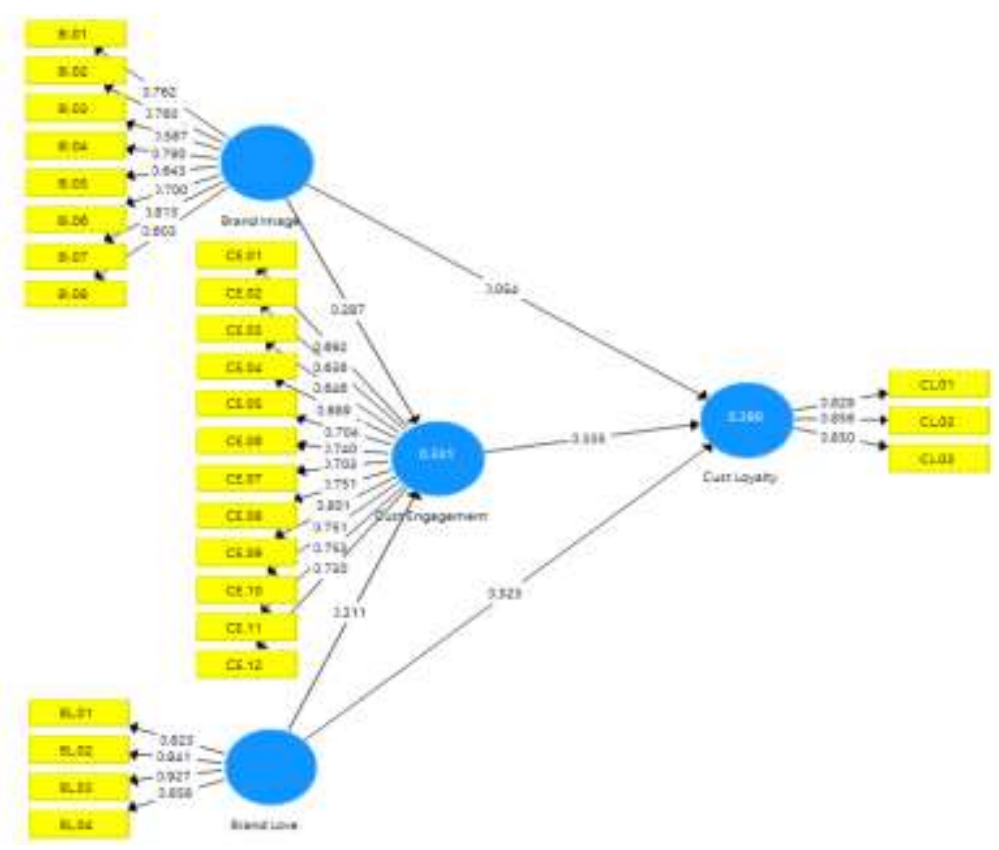

Figure 2. Path Diagram

\section{Sobel Method}

The Sobel method in this study was used to test the mediation hypothesis by testing the strength of the indirect effect of the independent variable $(X)$ on the dependent variable $(\mathrm{Y})$ through the intervening variable $(\mathrm{Z})$. The method of examining mediation variables refers to the theory put forward by Baron and Kenny (1986).

\section{RESEARCH RESULTS}

Model measurement evaluation uses convergent validity, discriminant validity and composite reliability criteria that are operated with the SmartPLS program. Convergent validity aims to determine the validity of each relationship between indicators and their latent variables. Convergent validity of the measurement model with reflective indicators is assessed based on the correlation between item scores or component scores with scores of latent variables or construct scores calculated by PLS. Based on the results of the convergent validity test, all the loading factor values of each item on the variable show values above 0.5 can be said to be valid (Ghozali, 2011). Thus each item on each variable is declared valid. The next measurement evaluation is to see discriminant validity with cross loading.

Discriminant validity of the measurement model was assessed based on the measurement of cross loading with the construct. If the construct correlation with the measurement principle (each indicator) is greater than the size of the other constructs, then the latent construct predicts the indicator is better than the other constructs. Based on the results of the discriminant validity test, each item on the variable representing the variable is better than the item in the other variables. Thus all items in this study meet the discriminant validity requirements. Analysis of the outer model by 
looking at the reliability of the construct of latent variables measured by two criteria, namely composite reliability and Cronbach's alpha from the indicator block that measures the construct. Constructions are declared reliable if the composite reliability value and Cronbach's alpha value are above 0.60. Based on the results of the composite reliability test, the model construct that was built in this study was declared reliable because it has a reliability composite value and Cronbach's alpha above o.6.

Tabel 1. Demography of Respondents

\begin{tabular}{llll}
\hline \multicolumn{1}{c}{ Variables } & & Total & $\%$ \\
\hline Age & $21-30$ & 120 & $80 \%$ \\
Last Education & $\leq$ SMA/SMK & 85 & $57 \%$ \\
Occupation & $\begin{array}{l}\text { Students/college } \\
\text { students }\end{array}$ & 96 & $64 \%$ \\
Income & $\begin{array}{l}\text { Rp 1 million - Rp 2 } \\
\text { million }\end{array}$ & 57 & $38 \%$ \\
\hline
\end{tabular}

Table 1 shows the demography of respondents. One hundred fifty respondents participated in this study. These respondents were the residence of Malang city who use product of Wardah.The demography information mentioned that $80 \%$ are aged between 21 - 30 years old, $57 \%$ the last education of respondents is $\leq \mathrm{SMA} / \mathrm{SMK}, 64 \%$ are students/college students and 38\% have income between Rp 1 and 2 million.

\section{Hypothesis Test}

This study consists of direct and indirect hypothesis testing. All hypothesis testing is carried out using $t$-statistics where $t$-statistics values greater than $t$-table values 1.96 with a significance level of 0.05 indicate a significant effect. The following are the results of hypothesis testing based on the PLS model formed.

Table 2. Result of Testing Direct Influence Hypothesis

\begin{tabular}{lllll}
\hline Variable & Coefficient & $\begin{array}{l}\text { Standard } \\
\text { Error }\end{array}$ & $\begin{array}{l}\mathrm{T} \\
\text { Statistics }\end{array}$ & Information \\
\hline $\mathrm{BI} \rightarrow \mathrm{CE}$ & 0.287 & 0.116 & 2.466 & Significant \\
$\mathrm{BI} \rightarrow \mathrm{CL}$ & 0.054 & 0.134 & 0.408 & Not \\
& & & & Significant \\
$\mathrm{BL} \rightarrow \mathrm{CE}$ & 0.311 & 0.121 & 2.563 & Significant \\
$\mathrm{BL} \rightarrow \mathrm{CL}$ & 0.323 & 0.139 & 2.320 & Significant \\
$\mathrm{CE} \rightarrow \mathrm{CL}$ & 0.335 & 0.076 & 4.388 & Significant \\
\hline
\end{tabular}

Hypothesis 1 proposes that brand image has a direct effect on customer engagement. Table 2 shows that Brand image (BI) has a positive influence on Customer Engagement (CE). The path coefficient obtained from the test results is 0.287 with a value of $t$ statistics of 2.466 . Because the value of $t$-statistics is greater than $t$-table $(2.466>1.96)$, the statistical hypothesis states $\mathrm{H} 1$ is accepted. Hypothesis 2 proposes that brand love has a direct effect on customer engagement. The path coefficient obtained from the test is 0.311 with a t-statistics value of 2.563 . Because the value of $t$-statistics is greater 
than t-table (2.563> 1.96), the statistical hypothesis states $\mathrm{H} 2$ is accepted, meaning that the variable Brand love (BL) has a significant effect on the Customer engagement (CE) variable. Hypothesis 3 proposes that customer engagement has a direct effect on customer loyalty. The test results obtained path coefficient is equal to 0.355 with a tstaistics value of 4.388 . Because the $t$-staistics value is greater than $t$-table $(4.388>1.96)$, the statistical hypothesis states that $\mathrm{H}_{3}$ is accepted, meaning that the variable Customer engagement $(C E)$ has a significant influence on the Customer loyalty $(C L)$ variable.

Hypothesis 4 in this study proposes that brand image has a direct effect on customer loyalty. The path coefficient obtained is 0.054 with $t$-statistics value of 0.408 . Because the $t$-statistics value is smaller than $t$-table $(0.408>1.96)$, the statistical hypothesis states that $\mathrm{Ho}$ is accepted, meaning that the Brand image variable (BI) has a non-significant effect on the Customer loyalty $(\mathrm{CL})$ variable. Brand love has a direct effect on customer loyalty proposed as the fifth hypothesis in this study. The result of the path coefficient test obtained is 0.323 with t-statistics value of 2.320 . The value of $t$-statistics is greater than $\mathrm{t}$-table $(2.320>1.96)$, the statistical hypothesis states that $\mathrm{H}_{5}$ is accepted, meaning that the variable Brand love $(B L)$ has a significant effect on the variable Customer loyalty $(\mathrm{CL})$.

Table 3. Result of Testing Indirect Influence Hypothesis

\begin{tabular}{ccccc}
\hline \multicolumn{1}{c}{ Variable } & Coefficient & p-value & t Statistics & Information \\
\hline $\mathrm{BI} \rightarrow \mathrm{CE} \rightarrow \mathrm{CL}$ & 0.287 & 0.030 & 2.157 & Significant \\
$\mathrm{BL} \rightarrow \mathrm{CE} \rightarrow \mathrm{CL}$ & 0.311 & 0.026 & 2.220 & Significant \\
\hline
\end{tabular}

Hypothesis 6 examines whether there is an indirect influence of brand image on customer loyalty through customer engagement. Based on the results of the sobel test, which calculates the Statistics $t$ value of the coefficient divided by the standard error and obtained $t$ Statistics 2.157, this value is greater than the value of $t$ Table 1.960 so that it can be said that there is an effect of brand image on customer loyalty through customer engagement.

The role of this mediation is full mediation because the results of testing the direct effect on $\mathrm{H} 4$ show an insignificant relationship of Brand Image to Customer Loyalty. Hypothesis 7 is tested to examined indirect influence of brand love on customer loyalty through customer engagement. Based on the results of the single test, it was obtained Statistics $2.220 \mathrm{t}$ value, this value is greater than the value of $t$ Table 1.960 so that it can be said that there is an influence of brand love on customer loyalty through customer engagement. The role of this mediation is partial mediation because the results of testing the direct effect on $\mathrm{H}_{5}$ indicate that the Brand love partially has a significant influence on Customer Loyalty.

This study provides an overview of Customer loyalty which is formed by Brand image, brand love and customer engagement. This study found that brand image significantly influenced customer engagement, consistent with prior studies by Doorn et al. (2010), Islam and Rahman (2016). Brand love significantly influences customer engagement, consistent with Islam and Rahman (2016). Brand image did not significantly influence 
customer loyalty, which was inconsistent with previous findings Carroll dan Ahuvia (2006), Loureiro, Ruediger, Kaufmann (2012).

This finding reveals the mediating role of customer engagement. The role of mediation the customer engagement of the relationship between brand image and customer loyalty is very important because it is full mediation. Brand love significantly influences customer loyalty, consistent with previous studies by Loureiro, Ruediger, Kaufmann (2012), Islam and Rahman (2016). In addition, the customer engagement mediates the relationship between Brand love and Customer Loyalty. The role of mediation customer engagement on the relationship between brand love and Customer loyalty is a partial mediation. Finally, the customer engagement significantly influences Customer loyalty, consistent with So et al., (2014), Brodie et al., (2011), Hollebeek et al., (2011). As a practical implication, the factor that must be considered by the company to improve Customer loyalty is making product packaging more attractive and exclusive and improving product quality so can make Wardah brand image better in customer's views. Wardah needs to create many more interesting and varied activities so that consumers will get closer to the company and will be more loyal.

\section{CONCLUSION}

Creating customer loyalty is important for all companies including cosmetics companies. Previous research has examined variables that affect customer loyalty, but few have tested brand love and customer engagement as variables that affect customer loyalty. Based on the results of the test in this study, brand image proved to be able to influence customer engagement, brand love proved to be able to influence customer engagement significantly, brand love was proven to be able to influence customer loyalty but the brand image was not proven to directly affect customer loyalty. Brand image is proven to be able to influence loyalty by means of customer engagement mediating variables. In addition, the results show that the customer engagement variable significantly affects customer loyalty directly. This study also shows that customer engagement is a mediating variable. The findings of this study are expected to provide practical and theoretical benefits.

\section{REFERENCES}

Aaker, D. A. (1996). Managing Brand Equity Capitalizing on The Value of a Brand Name. New York: The Free Press.

Baron, R. M.\& Kenny, D. A. (1986). The Moderator-Mediator Variable Distinction in Social Psychological Research: Conceptual, Strategic, and Statistical Considerations. Journal of Personality and Social Psychology, 51(6), 1173-1182.

Batra, R., Ahuvia, A., \& Bagozzi, R. P. (2012). Brand love. Journal of Marketing, 76, 1-16. doi:10.1509/jm.09.0339

Bergkvist, L., \& Bech-Larsen, T. (2010). Two studies of consequences and actionable antecedents of brand love. Brand Management, 17, 504-518. doi:10.1057/bm.2010.6 
Brodie, R. J., Hollebeek, L. D., Juric, B., \& Ilic, A. (2011). Customer engagement: Conceptual domain,fundamental propositions and implications for research in service marketing. Journal of Service Research, 14, 352-371. doi:10.1177/1094670511411703

Carroll, B. A., \& Ahuvia, A. (2006). Some antecedents and outcomes of brand love. Marketing Letters,7, 79-89. doi:10.1007/s11002-006-4219-2

Cho, E., Fiore, A. M., \& Russell, D. W. (2015). Validation of a fashion brand image scale capturing cognitive, sensory, and affective associations: Testing its role in an extended brand equity model. Psychology \& Marketing, 32(1), 28-48.

Doorn, V., Lemon, N., Mittal, V., Nass, S., Pick, D., Pirner, P., \& Verhoef, P. C. (2010). Customer engagement behaviour: Theoretical foundations and research directions. Journal of Service Research, 13, 253-266. doi:10.1177/109467051037559

Engel. J. F., Roger D. B., Paul .W.M. (1995). Perilaku Konsumen, edisi ke 6 jilid kedua. Jakarta : Binarupa Aksara.

Ghozali, I. (2011). Aplikasi Analisis Multivariate Dengan Program SPSS. Edisi keempat, Semarang : Penerbit Universitas Diponegoro.

Griffin, J (2005). Customer Loyalty: Menumbuhkan dan Mempertahankan Kesetiaan Pelanggan. Jakarta: Erlangga.

Hasan, A. (2008). Manajemen Pemasaran dan Marketing. Bandung : CV. Alfabeta

Hollebeek, L. D. (2011). Demystifying customer engagement: Exploring the loyalty nexus. Journal of Marketing Management, 27, 785-807. doi:10.1080/0267257X.2010.500132

Islam, J.U. and Rahman, Z. (2016). The transpiring journey of customer engagement research in marketing: a systematic review of the past decade. Management Decision, 54(8), 2008-2034.

Ismail , A. R., \& Spinelli , G., (2012). Effects of brand love, personality andimage on word of mouth The case of fashion brands among young consumers". Journal of Fashion Marketing and Management, 16 (4), 504-518

Kemenperin. (2012). Pasar Kosmetik Kurangi Potensi Impor. Diakses pada 20 Maret 2018 pukul 11:28, <http://www.kemenperin.go.id/artikel/4925/Pasar-Kosmetik-KurangiPotensi-Impor->.

Kotler, P \& Keller, K.L. (2012). Manajemen Pemasaran. Jilid 1, Edisi 13, Jakarta: Erlangga.

Kotler, P. \& Armstrong, G. (2012). Prinsip-prinsip Pemasaran. Edisi 13. Jilid 1. Jakarta: Erlangga.

Lewarissa, Adrianus SN. (2012). Pengaruh Brand Love Sebagai Faktor Mediasi antara Costumer Satisfaction terhadap Brand Loyality dan Positive Word Of Mouth Produk Notebook. Yogyakarta: Universitas Atma Jaya

Lin, Nan-Hong \& Lin, Bih-Shya. (2007). The Effect of Brand Image and Product Knowledge on Purchase Intention Moderated by Price Discount. Journal of International Management Studies.

Loureiro, S.M.C., Ruediger, K.H. and Demetris, V. (2012). Brand emotional connection and loyalty. Journal of Brand Management, 20(1), 13-27.

Lovelock, CH \& Wright, K.L. (2011). Manajemen pemasaran jasa. Jakarta: PT. Indeks. 
Marketing Science Institute (2010). Understanding Customer Experience and Behaviour: Research Priorities 2010-2012, Cambridge, MA, USA, diakses November 2016, www.msi.org/ research/2010-2012-research-priorities/

Patterson, P, Ting, Y, \& Ruyter, K. (2006). Understanding Customer engagement in Services. Paper read at ANZMAC 2006: Advancing Theory, Maintaining Relevance, at Brisbane QLD, diakses Mei 2018 http://www.anzmac.org/2006/ pattionson_paul

Reitz, A.R. (2012). Online Consumer Engagement: Understanding The Antecedents And Outcomes. Doctor of Philosophy Disertation, Colorado State University, diakses 7 Mei 2015.

Salinas,E. M. and Perez, J.M.P. (2009). Modeling the brand extensions influence on brand image . Journal of Business Research, 62, 50-60.

Schiffman, Leon G \& Kanuk, Leslie L. (2008). Perilaku konsumen, edisi ketujuh. Jakarta : PT.Indeks.

So, KKF, King, C \& Sparks, BA. (2014a). Customer engagement With Tourism Brands: Scale Development And Validation. Journal of Hospitality and Tourism Research, 38(3),304- 329

Sugiyono. (2011). Metode Penelitian Kuantitatif, Kualitatif dan R \& D. Jakarta: ALFABETA.

Surjaatmadja, S. (2008). Dasar-dasar Manajemen Merek. Malang: Bayumedia Publishing.

Verhoef,P.C., W.J. Reinartz, M. Krafft. (2010). Customer engagement as a New Perspective in Customer Managemen. Journal of Service Research, 13 (2010), 247252

Vivek, S. D., Beatty, S. E., \& Morgan, R. (2012). Customer engagement: Exploring customer relationships beyond purchase. Journal of Marketing Theory and Practice, 20, 122146. doi:10.2753/ MTP1069-6679200201 